\title{
PROBLEMS OF GENERAL BIOLOGY OF AGING
}

\author{
F. VERZÁR, Dr. med., Prof. emer. Physiology \\ (University of Basel, Switzerland)
}

This review is intended to be a comment upon trends in research and dominant themes during recent years and probable future developments of research in Europe upon the general biology of aging.

The present attitude toward experimental research on aging suffers from the mistakes which were made a generation ago, and it might therefore be interesting to consider what these were. First of all, we no longer see the aim of gerontologic research in the same way as 50 years ago. At that time the goal was the prolongation of human life. Now we have reached a state where, because of advances in hygiene and medicine, more people live to become old and the proportion of old people has thus increased to the extent that the new aim is to keep these older people in a healthy state for an enjoyable and active life. The second new point of view is that only such experiments which have scientific validity and are not based simply on subjective opinion or on one-sided observations are now acceptable; they must have all the criteria which are required in any physiologic study.

Looking back through my own time, I remember the sensational statement that the cause of aging was intoxication by intestinal bacteria. Metchnikoff, who was later a member of the Institut Pasteur, taught this concept and resorted to therapeutic measures even though no experimental proof for the theory existed. Another example is the work of BrownSéquard, the well-known French physiologist, who gave himself injections with extract of sex glands and believed in his own rejuvenation. This theory started a great deal of experimental work which finally proved that he was mistaken. A further illustration is provided by the work of Steinach, a first-class physiologist, whose studies on respiration, circulation, and internal secretion are of high value. Unfortunately the propaganda style in which his pupils and some surgeons used his experiments discredited his work and the word rejuvenation.

Similar activities are going on at the present time. Injections are given with embryonic cells; pills containing such cellular material are even produced commercially. At present we live in the period of the Bogomoletz-serum (13), and it is more difficult to find out whether or not this has the necessary scientific foundation. It is said to be an "antireticulocyte-serum," supposed to destroy the cells of connective tissue which are claimed to be deleterious for collagen fibers. It is prepared from extracts of lymph glands and spleen. Small doses were said to be cell-stimulating and therefore dangerous. From this basis, quite a number of scientists worked on the question and produced contradictory results. It was characteristic that at the Fourth International Gerontological Congress this item was the first to get into the daily newspapers. One should, however, read Foà's (29) criticism of this work.

I have mentioned these unfortunate examples to explain why there is a reluctance on the part of many to participate in experimental gerontology and why we have to prove again and again that gerontologic research, especially experimental research on aging, is in fact justified.

Until a few years ago it was often said that the problem of aging was identical with the problem of life and that far too little basic knowledge was available to work on aging alone. The history of physiology, however, has shown that useful experimental work is also possible along lines for which we do not have the basic facts. As research continues, one may hope to reach firmer ground.

\section{Some Present Problems in Experimental Gerontology}

I shall attempt to discuss some major problems of experimental gerontologic research which seem to me important at the present time. These are necessarily personal opinions, which may not coincide with the views of others.

The main lesson which I think we have gained from the fate of previous research into the process of aging is that any conclusions as to factors which are claimed to show an influence on aging can only be accepted if it can be proved scientifically that the biologic age of an individual has been influenced. We must therefore try to find satisfactory scientific tests 
to measure objectively the biologic age of individual animals or persons.

The simplest method is a survival test. If survival is prolonged by a certain factor, then that factor may be said to influence the aging process. This test has, however, several drawbacks: 1) it will take years before an answer can be given. The shortest lived experimental mammals are rats and mice, which have a life expectancy of about 50 per cent at 24 months. It is often not understood that there is no such thing as a fixed life span for any known species; even from an inbred colony, individuals die off in an S-shaped curve; 2) a large number of animals is needed for each test because only then can a 50 per cent survival be exactly measured, and even larger numbers would be needed if one wants to follow the animals until all are dead. The second point means that, if rats are used, not less than 100 or 200 animals must be kept for 2 years to prove whether a $50 \%$ survival at 24 months has been influenced. Thus in spite of the fact that survival experiments are undoubtedly the best tests, they can be used only as final proof.

Similarly age tests which involve killing the animal for certain histologic or chemical investigations have the drawback of irreversibility. Obvious morphologic changes are certainly of value; the plasticity of the skin, the graying of hair, etc. might be used, but all of these are rather inexact measurements and we are searching for more exact assessment. This might be provided by functional tests.

In man, the decrease of the visual accommodation capacity, the advance of presbyopy, is still probably the best and most exact test of biologic aging. Apart from men, only monkeys could be used, since other experimental animals do not seem to have a major optical accommodation.

Actually we are utilizing this fact at present in a longitudinal research problem on man (16). We have selected 200 people from a factory in which they generally work from youth to old age, and we are studying systematically the accommodation of the eye with all modern methods, while parallel tests are made by specialists on general health with the usual clinical methods. The team consists of an ophthalmologist, an internist, a dermatologist, and a physiologist, the latter determining pulse wave velocity as a possible measurement of elasticity of the blood vessels. Our problem is to dis- cover whether presbyopic changes run parallel with other changes, and if so, with which. This is, of course, a program for 30 or 40 years. Therefore the methods have been standardized, and we hope that the theme will go on when the present researchers will no longer be there.

I might remark that even the explanation of the primary fact, that visual accommodation decreases with age because of the decrease of elasticity of the lens, is not really settled. A distinct role is played by the tonus or the force of the ciliary muscle. It is interesting to see how this can be influenced by psychic factors, leading to astonishing changes in the visual capacity of old persons if they are brought from an old age home to a summer holiday place.

The other seemingly exact test, the measurement of pulse wave velocity, which is registered parallel with visual accommodations, certainly does register change with age, but the value of this test by itself is under discussion (52).

Bernstein (11), the famous mathematician, calculated life span from the development of presbyopy. Only a longitudinal research program can solve the question of whether this is possible. It is certainly not yet proved.

The accommodation of the eye and the changes of pulse wave velocity are functional tests. The most characteristic signs of aging are changes of adaptation, which is the general capacity of living organisms to live under continuously changing conditions. The adaptation capacity of metabolic equilibrium is probably the best characterization which can be given for "life." When this adaptability decreases, aging begins (68).

Such a point of view, of course, conflicts with the idea that aging starts with birth or even conception. Not every atrophic process is aging. The changes in ontogenetic evolution are not decreases of adaptation. On the contrary, evolution means increasing adaptation to new conditions; when the human embryo loses gills and tail, it has recapitulated a part of its adaptation from former generations to a completely changed evolutionary period. The greatest adaptation process is birth itself, when the individual is transferred to completely new life conditions. We therefore propose that problems of early evolution until puberty should not be mixed up with research on aging.

The newly born infant has to adapt himself to extra-uterine life; he now acquires heatregulation, enteric nutrition, etc. Thus he in- 
creases the range of his environment and acquires more and more potentials to meet the constantly changing conditions of life. Psychic evolution increases these possibilities still further, and the result is that man can now live in the Arctic or in the Tropics; he can fly in the stratosphere or descend 1000 meters underground.

However, from a certain age on, the adaptation capacity becomes less and less complete. This is well known for muscular efficiency in sports. The eye decreases in power of accommodation from the twelfth year on. If man lived under the conditions of wild animals, the decrease in muscular efficiency and visual accommodation would limit his lifetime to 50 years at most, because he would not see or fight his enemy in time. The limit of his life would be about the same as the reproductive life of his female partner. It is only through adaptation by psychic capacities that it is possible for man to survive longer, for only man is able to transfer the experience of a lifetime to the next generation, and to be still a useful member of society. This specific human factor of gerontology will be discussed by Welford.

I shall give you a few examples from my own laboratory of how the decrease of adaptation may or may not be used as a characteristic of aging and become a test for biologic age.

Adaptation to low temperature can be tested on rats (44). We transfer the animals to temperatures of $-1,-5,-11 \mathrm{C}$. for 1 hour. Young rats at $-1 \mathrm{C}$. do not change their body temperature to any marked degree, not even at -5 C. In 12-month-old animals one may, however, see individuals which have less efficient regulation, and with older animals it becomes progressively worse. At $-11 \mathrm{C}$. the body temperature of young animals may drop by 2 or $3 \mathrm{C}$. and of old animals by 8 or $10 \mathrm{C}$., which may lead to death. If these changes are studied on a large enough number of animals, one finds a continuous decrease in the capacity to regulate the body temperature, but one will also find large individual differences. There are some 6 -month-old animals which behave like the older ones, while there are some of 28 months which behave as if young. We do not believe that these disturbances could be explained by changes in sensitivity or changes in heat production caused by a decrease of muscular mass. It seems more probable that it is the heat regulatory center which has lost its ca- pacity of adaptation and thus of heat regulation. I should like to remark, however, that just lately it has been shown by Wertheimer (75) that a cooled animal's surviving diaphragm has an increased glucose-metabolism only in young and not in older animals. This would mean that there are certain endocrine metabolic factors involved.

Another adaptation test uses the capacity of animals to adapt to low atmospheric pressure (27). Rats are placed in a tank and the pressure decreased to $350 \mathrm{~mm}$. $\mathrm{Hg}$ within $30 \mathrm{~min}$ utes. Their rectal temperature drops 3 to $5 \mathrm{C}$. During the next 48 hours, a complete adaptation sets in, the body temperature again becomes normal (37-38 C.) in spite of the fact that the animals continue to live at low pressure. Even 12-month-old animals, and to an increasing extent 18,24, and 30-month-old animals, need a longer time to accommodate, and the oldest ones may never reach their normal body temperature again.

The mechanism of adaptation has not been explained definitely as yet. Endocrine activities of thyroid, adrenal, and pituitary are not responsible for the quick adaptation, and here again we believe that the disturbance lies in the decreasing capacity of the central nervous system for heat regulation.

Adaptation to low atmospheric or oxygen pressure involved another most interesting problem, namely, retained adaptation (28). If the animals are kept continuously for 2 weeks at the low pressure of $350 \mathrm{~mm}$. $\mathrm{Hg}$, they regain, as mentioned, a normal body temperature. We then take them out of the tank, keep them at $760 \mathrm{~mm} . \mathrm{Hg}$ pressure, and after two days place them again under low pressure, at which time their body temperature does not drop; they have retained their adaptation to low oxygen pressure. Only young animals, however, retain their adaptation; old animals do not. Again, aging in our rats as tested with the low pressure procedure starts as early as the twelfth month, although 50 per cent of our animals live 24 months and some even over 40 months. At present we have no explanation of the cause and mechanism of retained adaptation, but it might be worth studying this mechanism which changes in such a characteristic way with age.

I should like now to mention adaptation processes which do not show obvious changes with age. We have tested the work hypertrophy of the heart muscle (72). A silver ring is placed 
around the aorta to increase resistance, and in this way to produce hypertrophy of the left ventricle. This is an adaptation and we have found it to occur even in very old animals. It is true that especially old animals often do not tolerate this operation, and it may be that we have thus selected biologically young individuals with this test. However, similar observations have been made with other organs where the operative procedure does not lead to the death of the animals.

We also tested compensatory hypertrophy of the kidney after the extirpation of one (73). A month after the extirpation, the remaining kidney had grown to 140 per cent of the original weight. This capacity to compensate by hypertrophy is also maintained in old age. Similarly the compensatory hypertrophy of the adrenal gland was studied one month after extirpation of one gland. The second gland again increased to about 140 per cent. There are differences in compensatory hypertrophy between adult and old animals. It seems that the adult animal needs less hypertrophy to fulfill the increased work, while in young and in aged animals relatively more hypertrophy is necessary.

We do not forget, however, that, with aging, regressive processes are going on in these organs, as is known by pathologists, and a compensatory hypertrophy in old age is therefore the resultant between atrophic and hypertrophic processes. This has still to be analyzed.

May I remind you that it would be of great interest definitely to know whether Lecomte de Noüy's (50) cicatrization test can be used as a measurement of biologic age. This applies also to the test of Carell (50), which shows that the blood plasma of the aged inhibits the growth of fibroblasts in vitro, as well as to Schulz's recent statement (61) that the regeneration of fibrinogen decreases in the aged (this latter observation has not been worked out as a test).

Starting with the idea that changes in the tendons and joints in old age might be an expression of decreased adaptation capacity of the tissues to mechanical forces, we began to study the changes of connective tissue during aging. There are a number of illnesses which seem to be connected with aging, such as rheumatism, arthritis, sclerodermia, senile atrophy of the skin, and even atheromatosis and arteriosclerosis, in which connective tissue and especially elastic and collagen fibers are involved. These became known as collagenous diseases.

If one tests the elasticity of the skin in the simplest way, one sees very clearly a decrease with aging. The increase of pulse wave velocity in man shows also a decrease of elasticity of the arterial wall. It is more difficult to show the same changes in tendons and elastic bands by simple methods.

A few years ago interest was directed mainly to the elastic fibers. In 1949-1950 Banga and Baló $(5,6)$ published that they had isolated a new enzyme, elastase, which digests elastine. The latter can be prepared from the media of the aorta, a source of elastic fibers. Elastase is different from collagenase, which digests collagen. In their later papers (7-10), elastomucase is mentioned, however, which digests both. It is claimed that elastase can be crystallized, but the available preparations are generally contaminated with collagenase. Only the pancreas produces elastase. Baló, Banga, and Szabo (8) then suggested that elastase has a role in the aging of elastic fibers. An increase of elastase activity during life might lead to a destruction of elastine, especially in the aorta. Since, however, such an increase could be shown neither in the blood plasma nor in the pancreas, it was thought that there is a natural inhibitor of this enzyme during life and that it is this factor which decreases with age. The discussion continues. Saxl (60) recently described elastomucase activity in relation to the so-called clearing factor.

The study of these enzymes offered a good occasion to analyze the structure of collagen and elastine. Collagen is generally obtained from tendons and, after it is digested by collagenase, it becomes digestible with elastase also, like elastine. Banga (9) concluded that collagen is built up of two proteins: procollagen and metacollagen, and that between these two there is a mucoprotein 1 and a mucoprotein 2 . There is considerable discussion about the chemistry of collagen and an enormous literature on leather chemistry. I might refer to the excellent book of Gustavson (36) on the chemistry of collagen and to the papers of Randall (58), and also to the important Connective Tissue Symposium organized by cioms in London in 1956.

In the meantime the British group of Tunbridge, Hall, and others (15, 37, 38, 39, 40, 41, 63) had published new details on the structure 
of collagen and on the close relationship between these two fibrous components of connective tissue. In 1953 they declared that collagen can be transformed into elastine. A transition between these two substances had been suspected by Unna (66) 60 years ago by histologic methods. On the basis of differential staining, he distinguished between collagen, collacin, elacin, and elastine. The changes in aging skin especially are examples of transformation of collagen to elastine-like fibers.

A number of chemical analyses performed by Tunbridge's group also showed that there is a near relationship between collagen and elastine, except that collagen is rich in hydroxyproline whereas elastine contains almost none. The present opinion is that collagen contains a sequence of specific amino acids of which onethird is proline or hydroxyproline (33).

Gustavson (36) has supposed that the stability of collagen is bound up directly with the hydroxyproline content of the molecule. However, Hall's new experiments (39) have shown that, in old age, changes occur also with other amino acid components. He gives further evidence in support of the hypothesis that elastinelike fibers can be produced by the degradation of collagen. However, the breakdown with collagenase produces different fractions to the breakdown with phthalate buffer. We are certainly not dealing with a product which is chemically completely identical with elastine.

While these studies were going on, the Basel group has been studying changes of elasticity of'skin and tendons with age since 1951. We found $(66,67)$ that the single tendon fiber from a rat's tail, which is a pure collagen fiber, is an excellent object for research. Collagen fibrils show, as is well known, a beautiful periodic structure by electronmicroscopic examination. We showed that all tendon fibers present a helical structure even under low microscopic magnification (although only with special side-illumination). Studying the thermic contraction in Ringer's solution, we found that first the helical structure is destroyed; then the fiber contracts, becomes transparent and completely elastic. Since it was known that heat and certain substances like weak acids (acetic acid) liberate mucoprotein from collagen fibers, we suppose that the mucoprotein is localized along this helix on the fiber. The helix inhibits the contraction of the second part of the fiber. If the helix is dissolved, the fiber becomes elas- tic; it is then transformed, as previously mentioned, to an elastine-like substance. Since this name implies the existence of a chemical entity, we propose using the word "elastoid" instead.

There are differences in the thermic contraction of young and old fibers. It was found that the thermic contraction of young fibers can be inhibited with small weights while those of old animals are inhibited only with much larger ones. There are several other differences too. The smaller the weight, the lower is the activation temperature needed to make the fiber contract.

When the contraction has been produced, a second process starts, namely, an elongation of the fiber. Young animals' tendons are elongated by small weights; old animal fibers need much more weight. Finally, after thermic contraction, young animal fibers break with smaller weights than old animal fibers.

All this leads to the hypothesis that with aging cross-linkages are formed between the filamentous protein molecules which form the elastoid. The measurement of the weight which inhibits thermic contraction has given us a simple method of measuring the biologic age of a certain tendon fiber.

There is a possibility that aging of connective tissue leads to a reaction similar to thermic contraction. Such a theory, however, must also cxplain the fact that larger weights can be lifted at thermic contraction in an old than in a young tendon.

Further studies of this reaction (69) have shown that weak acids (such as acetic acid) give a slow contraction even at room temperature and at higher temperatures diminish the activation temperature for contraction. Since acids break hydrogen bonds, this is quite plausible.

There are, however, also other substances which influence this reaction, such as urea and urethane. They very distinctly decrease the activation temperature and also increase elasticity. They are well known for their capacity to break up cross-linkages.

A completely contrary effect is seen with formaldehyde and $\boldsymbol{\alpha}$-quinone; they enormously increase the weight which can inhibit thermic contraction. In young animals, this may be increased from 1 to $30 \mathrm{Gm}$., in old animals from 10 to $40 \mathrm{Gm}$. The elasticity is also decreased, but not for large weights, which can completely 
elongate these fibers again. These substances are known as tanning substances from their use in the leather industry. For us they have interest because the changes are similar to those found in aging, while acids and urethane change the behavior in the direction of young tissue.

Banga (9) and her group have studied a chemical contraction with $40 \%$ potassium iodide. This also dissolves the helix and thus leads to a contraction, even at room temperature. The fiber then also becomes extensible. Banga (10) has now confirmed that old animals' fibers break with larger weights, and larger weights are needed for extension to the original length. All this seems to be quite parallel to our findings with thermic contractions. Lately (10) she studied the action of several organic acids; the tendon fibers were treated with these acids, then dried and again tested with potassium iodide. The contraction time was decreased and the elongation increased. It seems that all this can be explained in the same way as with thermic contraction.

The best known example of aging of connective tissue is the atrophic changes of the skin in old age, where, according to Tunbridge (63), collagen fibers are transformed into elastin-like fibers. It is possible that this process is the same as in thermic contraction. The result is that while microscopic collagen fibers disappear and elastine-like fibers are somewhat increased, the elasticity of the tissue is much diminished. I think this is quite understandable. Collagen fibers form the architecture of the tissue; if they are destroyed, the elastic fibers contract and there is no practical use for their forces. Thus actually the tissue becomes less elastic.

There seems to be some possibility that a similar process goes on in the arterial wall. Up to now consideration has chiefly been given to the degenerative changes of the elastic fibers. If, however, the architecture of collagen fibers is destroyed in the same way as in the skin, the result will be the same as in the skin: the elasticity of the tissue decreases. It is thus possible that the age changes in the arterial wall affect not only elastic but also collagen fibers.

This theory does as yet not fit in with the findings in the tendons. Here, on the contrary, we see increased cross-linkaging with aging. Whether these phenomena can be connected with each other is at present unknown. It may well be that the primary age changes are in the ground substance of the connective tissue, where mucoproteins are produced in diminished quantities during aging. Since their role is the stabilizing of the collagen fiber, this would also lead to a decrease of stability. With regard to the aging of several different connective tissues, it seems possible that primarily a decreased action of tissue cells, fibroblasts, and consecutively a diminished production of mucoprotein is the main change. It is remarkable that research on arteriosclerosis is also pointing in the direction of metabolic changes of mucoproteins in the arterial wall and in blood plasma. The work of Greppi and his associates $(34,35)$ must be mentioned. It may be that one day aging of connective tissue can be related to changes in mucoprotein metabolism $(1,2,3,59)$.

Finally, let us turn to the problem of calcium metabolism, about which it is well known that changes occur with aging. There are facts which indicate that these are also the result of alterations in the connective tissue and especially in the collagen fibers. Actually it has been found $(30,70)$ that if $\mathrm{Ca}^{45}$ is injected into a rat and the radioactivity of the organs tested 48 hours later with a Geiger counter, the calcium uptake of several organs is higher in old than in young animals. The tendons, the lungs, and especially the aorta, show this difference; that is to say, tissues which are rich in collagen and elastine. During thermic contraction, when mucoprotein dissolves, the affinity to calcium increases. We studied this recently (71) with $\mathrm{Ca}^{45}$ and showed that thermic contraction, and especially the transparent stage of the isolated tendon fiber, increased the calcium-binding capacity from 100 to 221 or $278 \%$. If aging is a similar process, this might explain why aged animals' tendons bind more calcium than young ones.

Probably the study of connective tissue in aging has produced most understanding of basic changes during aging. These changes are in the protein molecule. Functional differences between young and old are secondary to these chemical changes. It will be the work of the future to study what these changes of the structure of the protein molecule are. May it be that increased cross-linkages are characteristic changes of aging? That might explain the decreased adaptation capacity of the collagen fiber, and one might be allowed-as has been done-to make the hypothesis that similar 
cross-linking might also be the cause of a decreased adaptation capacity of other tissues.

Thus I see the most promising future for the understanding of the process of aging in a detailed study of protein chemistry.

Some Current Experimental Gerontologic Work in Different European Countries:

The foregoing descriptions of current work were necessarily influenced by the present author's own special interests. The more difficult task will now be attempted of giving some data on the state of experimental gerontologic work in European countries. The countries will be mentioned alphabetically and in spite of important activities in some countries in clinical geriatrics and in social gerontology, information will be limited to examples of experimental work on aging. Apologies are offered for any omissions and it must be emphasized that the selection should not be regarded as an evaluation of merit but merely as a survey of different spheres of interest.

Austria: Austria's Gerontological Society held two conferences in 1956, mainly on geriatric problems; the transactions are edited by Doberauer (24) in a volume with 30 lectures on different aspects of aging.

Belgium: In Belgium, where the International Association of Gerontology was founded in 1950, Brull has an excellent clinical department at the University of Liège with laboratories for experimental work. Brull (17) recently discussed the changes in chemical constitution which occur with age.

Divry, professor of psychiatry in Liège, is interested in the histologic changes during aging in the central nervous ssytem, especially in amyloidosis (23).

Finland: Finland's Gerontological Society publishes a yearbook, Geron, with summaries of the papers in English. Karsten, Jalavisto, and Tunkelo are on the Editorial Board. Many of the papers published have psychologic, social, or geriatric aspects. One experimental gerontologic paper is that of Fieandt (25), Personal Tempo and Phenomenal Time at Different Age Levels. A paper from Jalavisto's laboratory deals with the relation of aging to stimulus intensity (45). It is impressive to read about large donations to the research center of the Gerontological Society for experimental researeh en entronic hormones, sensibility of the cornea, and adaptation to environment.
France: In France there is the new Centre d' Etudes et de Recherches Gérontologiques in Paris, founded 1950 by Huet, from which you will have direct information from Bourlière. The excellent textbook by Binet and Bourlière (12) is the best proof of the high quality of experimental research on aging in that country. Bourlière will give a review of their work in comparative physiology. His own researches with Joseph and Molinard on aging of the skin (14) should be especially mentioned as an adaptation of physico-chemical methods to studies on aging of a tissue. There is also a Société de Gérontologie de Bordeaux et du SudOuest which was founded in 1956.

Germany: In Germany gerontologic research started a long time ago. Abderhalden founded the Zeitschrift für Altersforschung, which is now edited by Bürger in Leipzig and which has reached its tenth volume. A large part of its content are papers from his own group. Systematic research in age changes in different organs (eye, cartilage, etc.) has been carried out in a very exact way. Bürger (18) has summarized these studies in his book, Altern und Krankheit, published 1957 in the third edition.

Many of the publications in the above mentioned journal are in the field of clinical gerontology; only a few papers deal with experimental work on animals. Of special interest lately are papers on the changes of plasma protein fractions with age in Wistar rats by Uebel (64) and by Nöcker and Bemm (54). Age changes in the chemistry of muscles are published by Lohmann, Wielepp, and Nöcker (51) and changes measured with myometric methods by Bajusz (4). Bürger (18) reviewed the nucleotide and ganglioside content of the human central nervous system in aging. Morphologic changes, studied especially by Wahren (74) from Vogt's laboratory and audiometric work by Fleischer (26) should be mentioned.

Great Britain: The British Society for Research on Ageing has produced excellent experimental work. Korenchevsky is the senior experimental gerontologist in this country. Not only has his continuous stimulation in England and other countries led to the formation of various gerontologic societies, but it has produced a large number of publications in different fields of research on aging. Recently, in Whittington Hospital he has worked on autointoxication as connected with aging (48) and 
has summarized this work in his lecture at the Symposium on Experimental Gerontology (49).

Comfort's book on the Biology of Senescence (19) contains a large amount of material on the comparative biology of aging.

The important work of Tunbridge, Hall, and their associates $(15,37,38,39,40,41,63)$ on connective tissue has already been referred to. Danielli works on the aging of single cells (20). Olbrich, whose early death is a great loss, worked on water metabolism (55). The Nuffield Foundation has given support to several research units in this country, such as the Experimental Psychological team of Welford in Cambridge, and the Experimental Physiological team of Franklin in St. Bartholemew's Hospital in London, where interesting experiments are being made by Lindop and others.

Special mention should also be made of the activities of the Ciba Foundation in London, which has published three volumes of Colloquia on Aging reporting research on aging from all over the world. The Ciba Foundation is also famous for the Ciba awards which have been given for the last three years for papers on gerontology.

Holland: In Holland the Gerontological Society has the support of Mühlbock at the Cancer Research Institute and clinicians such as Groen. Mühlbock works on experimental cancer (53) and his co-worker, Thung, has studied amyloidosis (62).

Hungary: Hungary has a very active Gerontological Research group. Banga and Baló and their co-workers (5-10) are well known for their research on collagen and elastic fibers and on elastase. Another group is that of Haranghy (42), who, as a pathologist, works with histologic methods on tissue changes connected with experimental work on conditioned reflexes (43).

It should be mentioned that interest in gerontology in this country was high as long as 20 years ago, especially under the stimulating influence of Professor Alexander Korányi, the internist.

Italy: Since 1953, the Giornale di Gerontologia, edited by Greppi in Florence and now in its fifth volume, is the official publication of the Gerontological Society. Its contents pertain mainly to geriatrics. A number of conferences have been organized and many articles have been published from papers presented. Attention may be called to the work of Antonini, Mininni, and Salvini (1-3) summarized in 1957 in the Symposium on Arteriosclerosis; and to the work of Salvini, Scardigli, and Guidi (59), Galletti and Abbatti (3I) and Greppi $(34,35)$ on arteriosclerosis, all working in Florence.

Another group is that of Di Macco $(21,22)$ in Rome, who has published work on changes with age in the reaction to cholinergic stimuli, in several different journals on physiology and pathology and in the Symposium on Experimental Research on Ageing in Basel in 1956.

There is also another journal in Italy concerned with the problems of old age: the Archivio di Medicina Mutualistica, published by the Istituto Nazionale per l' Assicurazione contro le Malatie, which reached its fifth volume in 1957. I should like to mention certain articles of it, such as Foà's Illusioni e Possibilità in Temadi Profilassi della Vecchiata (29). Di Macco's Aspetti Biologici e Patologici della Senescenza (22), and Greppi's La Vecchiata come Mallattia e l' Invecchiamento come sua Fase Precoce (34).

Other Italian journals are Longevità, Acta Gerontologica, Archiva de Vecchi, and Revista de Gerontologia e Geriatria.

Roumania. Research on problems of gerontology goes back to Marinesco, who worked on neurologic problems and to Parhon (57), who worked on endocrinology. The latter is the Director of the Institute of Gerontology and Geriatrics in Bucarest, which was founded in 1944, and since 1951 has had a clinical division for the aged and a research division. Parhon, with Aslan, reported at the 1956 Symposium on Experimental Gerontology (56) on novocain therapy in relation to aging, for which excellent results were claimed.

Switzerland: The Gerontological Society of Switzerland, which was founded in 1953, held a Symposium in Basel in 1954 on The Possibility of Experimental Research on Ageing and in 1956 an International Symposium, sponsored by the European section of the Biological and Medical Research Committee of the International Gerontological Association. The transactions of the latter contain 40 papers. The lectures were very heterogenic, but they gave a good picture of the work which is going on in Europe. The intention was to learn who is working in the field of gerontology, and in which directions. Papers given by the different authors have been quoted above.

A small laboratory of Experimental Gerontology has existed since 1956 in the Institute of 
Anatomy of the University of Basel, led by the present author, where also a journal for experimental gerontology (Gerontologia) is edited.

\section{Other countries:}

In Denmark Professor Geill (32) has worked with great activity on problems of blood coagulation in the aged.

In Ireland Professor Jessop (46) has studied carbohydrate metabolism in the aged.

The Gerontological Societies of Sweden, Norway, Spain, and Portugal seem as yet to be mainly interested in social and geriatric problems.

\section{REFERENCES}

1. Antonini, F. M., and Salvini, L.: Applicazione del Elettroforesi su Carta allo Studio del Metabolismo Proteico e Lipoproteico nell' Aterosclerosi Umani. Gior. Gerontol., 1: 207-217, 1953.

2. Antonini, F. M., and Mininni, G.: Studio sui Mucopolisaccaridi Plasmatici e dell' Aorta nell'Aterosclerosi Sperimentale da Colesterolo. Arch. Biochim. ital., 17: 28-32, 1955.

3. Antonini, F. M., and Salvini, L.: Mucopolysaccharides, "Clearing Factor," Age and Arteriosclerosis. Bull. Acad. Suisse Scs. Med., 13: 209-228, 1957.

4. Bajusz, E.: Die Beziehungen einiger myometrischer und myographischer Untersuchungsergebnisse zur Gerontologie. Ztschr. f. Alternsforsch., 10: 27-39, 1956.

5. Baló, I., and Banga, I.: Elastase and Elastase Inhibitor. Nature, 164: 491-498, 1949.

6. Baló, I., and Banga, I.: Elastic Activity. Biochem. J. 46: 384-390, 1950.

7. Baló, I., and Banga, I.: Vergleichende Untersuchungen über Elastolyse. Acta morphol. Hung., 4: 141-151, 1954.

8. Baló, I., Banga, I., and Szabo, D.: Studies of Elastolysis. Acta physiol. Hung., 6: 235-247, 391400, 1956.

9. Banga, I.: On the Structure of Collagen Fibre. Acta morphol. Sci. Hung., 4: 33-40, 1954.

10. Banga, I.: Der Effekt der schwachen organischen Säuren auf die Rattenschwanz-Kollagenfasern von jungen. und alten Tieren. Gerontologia, 1: 325346, 1957.

11. Bernstein, F.: Law of Physiologic Ageing as Derived from Long Range Data on Refraction of the Human Eye. Arch. Ophth., 34: 378-388, 1945.

12. Binet, L., and Bourlière, F.: Précis de Gérontologie, Masson, Paris, 1955.

13. Bogomoletz, V.: The Secret of Keeping Young. Arco Publications Ltd., London, 1954.

14. Bourlière, F., Joseph, N. R., and Molinard, R.: Ageing of Skin. 2. Adaptive Responses in Rat Dermis in Relation to Age and Growth. Gerontologia, 1: 18-40, 163-173, 1957.

15. Burton, D., Hall, D. A., Keech, M. K., Reed, R., Saxl, H., Tunbridge, R. E., and Wood, M. J.: Apparent Transformation of Collagen Fibrils into 'Elastin.' Nature, 176: 966-969, 1955.
16. Brückner, R., Gsell, O., Hügin, F., Batschelet, E., and Verzár, F.: Fortlaufende Erfassung des Alternsprozesses. In: Experimentelle Alternsforschung, F. Verzár, ed. Birkhäuser Verlag, Basel and Stuttgart, 1956.

17. Brull, L., and Keil, C.: Chemical Constitution of the Mouse According to Age. In: Experimentelle Alternsforschung, F. Verzár, ed. Birkhäuser Verlag, Basel and Stuttgart, 1956.

18. Bürger, M.: Altern und Krankheit. 3rd ed. Thieme, Leipzig, 1957.

19. Comfort, A.: The Biology of Senescence. Rinehart Co., New York, 1956.

20. Danielli, J. F.: On the Ageing of Cells in Tissues. In: Experimentelle Alternsforschung, F. Verzár, ed. Birkhäuser Verlag, Basel and Stuttgart, 1956.

21. Di Macco, G.: La Toxicose Acétycholinique et Ganglioplégique dans l' Age Avancé. In: Experimentelle Alternsforschung, F. Verzár, ed. Birkhäuser Verlag, Basel and Stuttgart, 1956.

22. Di Macco, G.: Aspetti Biologici e Patologici della Senescenza. Arch. Medic. Mutualistica, 5: 61-126, 1957.

23. Divry, P.: De la Notion d'Amyloidose Cérébrale dans les Processus Séniles. In Experimentelle Alternsforschung, F. Verzár, ed. Birkhäuser Verlag, Basel and Stuttgart, 1956.

24. Doberauer, W.: Alter und Krankheit. Gesellschaft zur Förderung wissenschaftlicher Forschung, Vienna, 1957.

25. Fieandt, K.: Personal Tempo and Phenomenal Time at Different Age Levels. Geron., 8: 85-101, 1956.

26. Fleischer, K.: Audiometrische Untersuchungen über die Altersschwerhörigkeit. Ztschr. f. Alternsforsch., 10: 70-83, 1956.

27. Flückiger, E., and Verzár, F.: Senkung und Restitution der Körpertemperatur bei niedrigem atmosphärischem Druck. Helvet. physiol. et pharmacol. acta, 10: 349-359, 1952.

28. Flückiger, E., and Verzár, F.: Ueberdauern der Adaptation an niedrigem atmosphärischem Druck. Helvet. physiol. et pharmacol. acta, 11: 67-87, 1953.

29. Foà, C.: Illusioni e Possibilità in Temadi Profilassi della Vecchiata. Arch. Med. Mutualistica, 5: 31-57, 1957.

30. Freydberg-Lucas, V., and Verzár, F.: Der Calciumstoffwechsel verschiedener Organe bei jungen and alten Tieren. Gerontologia, 1: 196-212, 1957.

31. Galetti, F., and Abbatti, A.: Eparina e Arteriosclerosi. Gior. Gerontol., 5: 679-683, 1957.

32. Geill, T.: Studies on Blood Coagulation in Old Age. In: Experimentelle Alternsforschung, F. Verzár, ed. Birkhäuser Verlag, Basel and Stuttgart, 1956.

33. Grassmann, W.: Aminoacid Sequences of Collagen. Symposium on Connective Tissue. Blackwell, London, 1957, 308-321.

34. Greppi, E.: La Vecchiata come Malattia e l' Invecchiamento come sua Fase Precoce. Arch. Medic. Mutualistica, 5: 129-162, 1957.

35. Greppi, E.: L' Aterosclerosi: Patologia Metabolico Vascolare dell' Uomo, nel Quadro Biologico e Clinico dell' Invecchiamento. Gior. Gerontol., 5: 649-664, 1957. 
36. Gustavson, K. H.: The Chemistry and Reactivity of Collagen. Academic Press, New York, 1956.

37. Hall, D. A.: Elastin from Human Tissue and from Ox Ligament. Nature, 168: 513, 1951.

38. Hall, D. A.: Thermal Contraction of Collagen and Its Dissolution with Elastase. Nature, 172: 10991100, 1953.

39. Hall, D. A.: Collagen and Elastin: The Effect of Age on Their Relationship. Gerontologia, 1: 347363, 1957.

40. Hall, D. A., Reed, R., and Tunbridge, R. E.: Structure of Elastic Tissue. Nature, 170: 264-266, 1952.

41. Hall, D. A., Reed, R., and Tunbridge, R. E.: Electron Microscope Studies of Elastic Tissue. Exper. Cell. Res., 8: 35-48, 1955.

42. Haranghy, L.: Reaktionsformen der Milz und des Knochenmarks bei Säuglingen mit mehreren aufeinanderfolgenden Schädigungen, Acta Med. Hung., 6: 117-134, 1954.

43. Haranghy, L., Rácz, P., Hársfalvy, E., and Király, F.: Sclerosis of the Spleen in Old Age and Concomitant Changes of the Bone Marrow, In: Experimentelle Alternsforschung, F. Verzár, ed. Birkhäuser Verlag, Basel and Stuttgart, 1956.

44. Hügin, F., and Verzár, F.: Versagen der Wärmeregulation bei Kälte als Alterserscheinung. In: Experimentelle Alternsforschung, F. Verzár ed. Birkhäuser Verlag, Basel and Stuttgart, 1956.

45. Jalavisto, E., Orma, E., and Tawast, M.: Ageing and Relation Between Stimulus Intensity and Duration in Corneal Sensibility. Acta physiol. scandinav. 23: 224-334, 1951.

46. Jessop, W. J. E.: The Effect of Ageing on Carbohydrate Metabolism. In: Experimentelle Alternsforschung, F. Verzár, ed. Birkhäuser Verlag, Basel and Stuttgart, 1956.

47. Korenchevsky, V., Paris, S. K., and Benjamin, B.: Treatment of Senescence in Male Rats with Sex and Thyroid Hormones and Desoxycorticosterone Acetate. J. Gerontol., 8: 415-434, 1953.

48. Korenchevsky, V.: Treatment of Senescent Male Rats with Cortisone Acetate Alone or Together with Sex and Thyroid Hormones. J. Gerontol., 11: 261-267, 1956.

49. Korenchevsky, V.: Problem of Autointoxication in Gerontology. In: Experimentelle Alternsforschung, F. Verzár, ed. Birkhäuser Verlag, Basel and Stuttgart, 1956.

50. Lecomte de Noüy, P.: Cicatrization of Wounds. J. Exper. Med., 24: 451-460, 461-470, 1916.

51. Lohmann, D., Wielepp, G., and Nöcker, J.: Age Changes in Muscles. Ztschr. f. Alternsforsch., 10: 233-238, 1956.

52. Michel, D., and Hartleb, O.: Kritische Betrachtungen zur Brauchbarkeit der Pulswellengeschwindigkeit als Altersindex. Ztschr. f. Alternsforsch., 10: 296-306, 1957.

53. Mühlbock, O.: Advanced Parental Age and Spontaneous Cancer in Mice. In: Experimentelle Alternsforschung, F. Verzár, ed. Birkhäuser Verlag, Basel and Stuttgart, 1956.

54. Nöcker, J., and Bemm, H.: Einwirkung des Alters auf die Serumproteine. Ztschr. f. Alternsforsch., 9: 222-232, 1955, 328-339, 1956.
55. Olbrich, O., Ferguson, M. H., Robson, J. S., and Stewart, C. P.: Renal Function in Aged Subjects. Edinburgh M. J., 57: 117-127, 1950.

56. Parhon, C. J., and Aslan, A.: Discussion. In: Experimentelle Alternsforschung, F. Verzár, ed. Birkhäuser Verlag, Basel and Stuttgart, 1956.

57. Parhon, C. I., and Milcu, S. M.: The Rumanian Endocrinological Institute. Foreign Languages Publishing House, Bucharest, 1957.

58. Randall, I. T.: Nature and Structure of Collagen. Butterworths, London, 1953.

59. Salvini, L., Scardigli, G., and Guidi, G.: Il Carico Lipidico Prolungato in Soggetti Normali ed in Aterosclerotici. Gior. Gerontol., 5: 48-66, 1957.

60. Saxl, H.: The Physiological Significance of the Reaction Between Elastin and Elastomucase in Relation to the Production of "Clearing Factor." Gerontologia, 1: 142-163, 1957.

61. Schulz, F. H.: Fibrinogen Regeneration During Ageing. Ztschr. f. Alternsforsch. 5: 192-203, 1951, 10: 318-324, 1957.

62. Thung, P. J.: Senile Amyloidosis in Mice. Gerontologia, 1: 259-269, 1957.

63. Tunbridge, R. E., Tattersall, R. N., Hall, D. A., Astbury, W. T., and Reed, R.: Apparent Transformation of Collagen Fibrils into "Elastin." Clinical Sci., 11: 315-325, 1952.

64. Uebel, H.: Úber alternsabhängige Verschiebungen der Serumeiweisskörper bei Wistarratten. Ztschr. f. Alternsforsch., 10: 149-152, 1956.

65. Unna, P. G.: Elastin und Elacin. Monatsh. prakt. Dermat., 19: 339-402, 1894.

66. Verzár, F.: Das Altern des Kollagens. Helvet. physiol. et pharmacol. acta, 14: 207-227, 1956, Connective Tissue Symposium, R. E. Tunbridge, ed., Oxford, 1956.

67. Verzár, F.: The Ageing of Connective Tissue. Gerontologia, 1: 363-378, 1957.

68. Verzár, F.: Studies on Adaptation as a Method of Gerontological Research. Ciba Foundation Colloquia on Ageing, 3: 60-68, 1957.

69. Verzár, F.: Influence of Different Chemical Substances on Collagen Fibers of Young and Old Animals. Gerontologia, 2: in press, 1958.

70. Verzár, F., and Freydberg-Lucas, V.: $\mathrm{Ca}^{45}$ Turnover in Young and Old Animals. In: Experimentelle Alternsforschung, F. Verzár, ed. Birkhäuser Verlag, Basel and Stuttgart, 1956.

71. Verzár, F., and Freydberg-Lucas, V.: $\mathrm{Ca}^{45}$ Uptake and Turnover of Tendon Fibers Influenced by Thermic-contraction and Age. Gerontologia, 2: 10-20, 1958.

72. Verzár, F., and Hügin, F.: Untersuchungen über die Arbeitshypertrophie des Herzens bei jungen und alten Ratten. Arch. ges. Physiol., 262: 181-191, 1956.

73. Verzár, F.: and Hügin, F.: Einfluss des Alters auf die Entwicklung der Arbeitshypertrophie von Organen. Anat. Acta, 30: 918-927, 1957.

74. Wahren, W.: Neurohistologischer Beitrag zu Fragen des Alterns. Ztschr. f. Alternsforsch., 10: 343-356, 1957.

75. Wertheimer, E., and Bentor, V.: Adaptation of Young and Old Rats to Short Cold Exposure. Gerontologia, 1: 306-312, 1957. 